\title{
Semen quality as a potential susceptibility indicator to SARS-CoV-2 insults in polluted areas
}

\author{
Luigi Montano ${ }^{1}$ (D) $\cdot$ Francesco Donato ${ }^{2} \cdot$ Pietro Massimiliano Bianco $^{3} \cdot$ Gennaro Lettieri ${ }^{4} \cdot$ Antonino Guglielmino $^{5}$. \\ Oriana Motta ${ }^{6} \cdot \operatorname{lan}$ Marc Bonapace ${ }^{7} \cdot$ Marina Piscopo $^{4}$ (ID
}

Received: 8 April 2021 / Accepted: 21 May 2021 / Published online: 29 May 2021

(C) The Author(s) 2021

\begin{abstract}
The epidemic of the new severe acute respiratory syndrome coronavirus 2 (SARS-CoV-2) has impacted worldwide with its infectious spread and mortality rate. Thousands of articles have been published to tackle this crisis and many of these have indicated that high air pollution levels may be a contributing factor to high outbreak rates of COVID-19. Atmospheric pollutants, indeed, producing oxidative stress, inflammation, immuno-unbalance, and systemic coagulation, may be a possible significant co-factor of further damage, rendering the body prone to infections by a variety of pathogens, including viruses. Spermatozoa are extremely responsive to prooxidative effects produced by environmental pollutants and may serve as a powerful alert that signals the extent that environmental pressure, in a specific area, is doing damage to humans. In order to improve our current knowledge on this topic, this review article summarizes the relevant current observations emphasizing the weight that environmental pollution has on the sensitivity of a given population to several diseases and how semen quality, may be a potential indicator of sensitivity for virus insults (including SARS-CoV-2) in high polluted areas, and help to predict the risk for harmful effects of the SARS-CoV-2 epidemic. In addition, this review focused on the potential routes of virus transmission that may represent a population health risk and also identified the areas of critical importance that require urgent research to assess and manage the COVID-19 outbreak.
\end{abstract}

Keywords Air pollution $\cdot$ COVID-19 $\cdot$ Semen quality $\cdot$ Environmental marker $\cdot$ Health marker $\cdot$ Oxidative stress $\cdot$ SARS-CoV-2

Responsible Editor: Lotfi Aleya

Luigi Montano

luigimontano@gmail.com

Ian Marc Bonapace

ian.bonapace@uninsubria.it

Marina Piscopo

marina.piscopo@unina.it

Francesco Donato

francesco.donato@unibs.it

Pietro Massimiliano Bianco pietro.banco@isprambiente.it

Gennaro Lettieri

gennarole@outlook.com

Antonino Guglielmino

angug12017@gmail.com

Oriana Motta

omotta@unisa.it
1 Andrology Unit, EcoFoodFertility Project, Coordination Unit, Local Health Authority (ASL) Salerno, Oliveto Citra, Via M. Clemente, 84020 Oliveto Citra, SA, Italy

2 Department of Medical and Surgical Specialties Radiological Sciences and Public Health, Unit of Hygiene, Epidemiology, and Public Health, University of Brescia, Brescia, Italy

3 ISPRA, Italian Institute for Environmental Protection and Research, Via Vitaliano Brancati 60, 00144 Rome, Italy

4 Department of Biology, University of Naples Federico II, Via Cinthia 21, 80126 Napoli, Italy

5 Unit of Reproductive Medicine (UMR) Catania, Catania, Italy

6 Department of Medicine, Surgery and Dentistry, University of Salerno, Fisciano, Italy

7 Department of Biotechnology and Life Sciences, University of Insubria (VA), Varese, Italy 


\section{Introduction}

Coronavirus disease 2019 (COVID-19) due to a new betacoronavirus severe acute respiratory syndrome coronavirus 2 (SARS-CoV-2) has so far affected almost all countries releasing international panic and alarm. At the time of writing, there have been approximately 120,000,000 confirmed cases and 266 million deaths worldwide. SARS-CoV-2 was first observed in Wuhan, China, in December 2019. However, some reports refer to previous detection of the virus in clinical samples and wastewater in many Western countries (Deslandes et al. 2020; Chavarria-Miró et al. 2020). The virus is very strong and is able to persist in the environment for a relatively long time and preserves its infectivity during this period. Many researchers have discussed the reasons why coronavirus (COVID-19) has spread, persists, and has high contagiousness. An increasing number of studies demonstrate a tight association between chronic exposure to some air pollutants and the transmission and severity of the effects caused by infection of the SARSCoV-2 virus (Domingo and Rovira 2020). In particular, recent papers strongly associated the exposure to PM2.5 to deaths caused by COVID-19. In addition, the association of ambient air pollutants and meteorological variables with the incidence of COVID-19 has also proposed (Jiang et al. 2020). The stability of SARS-CoV-2 under different environmental conditions supports the hypothesis that air pollution may promote the chain of human-to-human transmission of infection, particularly in situations of high crowding, COVID-19 severity and related risk of death (Domingo and Rovira 2020). In addition, chronic exposure to PM2.5 not only induces inflammation to the alveolar district but also oxidative stress, facilitating the pathogen virulence (Ghio et al. 2012; Li et al. 2019; Tsai et al. 2019; Caso et al. 2020). Recently, human semen is not only considered an early biomarker for monitoring the impact of adverse environmental exposures (Nordkap et al. 2012; Bergamo et al. 2016) but also reflects individuals' general health condition. In fact, a link between semen quality and the onset of chronic diseases, with male infertility serving as an early predictor of future hospitalization and overall mortality (Jensen et al. 2009; Eisenberg et al. 2015; Pisarska 2017; Choy and Eisenberg 2018).

This review focuses on the evidence that correlates the degree and type of pollution with the increased susceptibility of many countries to this pandemic and proposes human semen as an early marker of the environmental health and of the general health of individuals. These evidences could be useful to suggest an activation of a control policy based on the evaluation of the reproductive health of a given population mainly for those areas at high environmental impact in which already a reduction in fertility or alterations in the spermiogram parameters has been found.

\section{Air pollution and COVID-19}

Evaluating if long-term exposure to air pollution enhances severity from COVID-19 health outcomes is essential to public health. Indeed, many works indicate that air pollution is an influencing cofactor for the enhanced risk of COVID-19 incidence and mortality (Karan et al. 2020; Fattorini and Regoli 2020; Pozzer et al. 2020; Holme et al. 2020). It is well known that air pollution rates are higher in the winter period, and the cities where COVID-19 had the hardest impact are the one with the annual average PM10, PM2.5, and NO2 above the WHO recommended values of $20 \mu \mathrm{g} / \mathrm{m}^{3}, 10 \mu \mathrm{g} / \mathrm{m}^{3}$, and 40 $\mu \mathrm{g} / \mathrm{m}^{3}$ respectively, like in Wuhan and in other Chinese cities (https://www.kaggle.com/) (Beloconi et al. 2018; Wu et al. 2020b; Pansini and Fornacca 2020a; Paital and Agrawal 2020) (Fig. 1).

Specifically, in Wuhan, a higher mortality rate (CFR) of COVID-19 was also found to be related to the increase in air particulate matter with a diameter of $10 \mu \mathrm{m}$ (PM10) or less (PM2.5) after adjusting for humidity and temperature (Yao et al. 2020). It is noteworthy that already at the time of the 2003 SARS-CoV-1 infection in China, the CFR in the most polluted areas resulted twice as high in comparison with the least polluted ones (Cui et al. 2003). In addition, in a recent preprint, analyzing China, Italy, and the USA, a significant association was shown between elevated levels of PM2.5, carbon monoxide (CO), nitrogen dioxide (NO2), and COVID-19 diffusion and mortality (Pansini and Fornacca 2020b). Two very recent papers strongly associate PM2.5 exposure with deaths caused by COVID-19. The first, published by Wu et al. (2020a), shows that the highest rates of COVID deaths ascribed to human-caused exposure to particulates matter were in this order: highest in East Asia $(\sim 35 \%)$, Central Europe $(\sim 25 \%)$ and Eastern USA ( 25\%) (Pozzer et al. 2020). These world regions exhibit very high levels of fossil fuel utilization (Pozzer et al. 2020). A second paper instead reports preliminary investigations of this question in the USA, and shows that higher PM2.5 exposures were positively linked to higher COVID-19 mortality rates at the county level after taking into account many area-level confounders. Specifically, in this latter study, a $1 \mu \mathrm{g} / \mathrm{m} 3$ increase in longterm average PM2.5 was related with a statistically significant $11 \%$ increase in COVID-19 mortality in the county (Wu et al. 2020a). Numerous further studies are in line with these findings. For example, a study performed in Italy indicated that more than $75 \%$ of infected individuals and about $81 \%$ of deaths in the first wave of the COVID-19 pandemic in Italy happened in industrialized regions with high levels of air pollution (Skirienè and Stasiškienè 2021). More specifically, it was observed that infected people were higher in those cities that exceeded the set limits for PM10 or ozone for 100-plus days per year, in those cities situated in inland areas (i.e., away from the coast), in cities with low average wind speeds, and in 


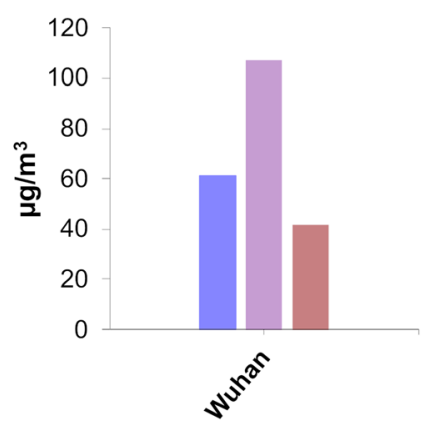

PM $2.5 \backsim$ PM 10 Nitrogen dioxide

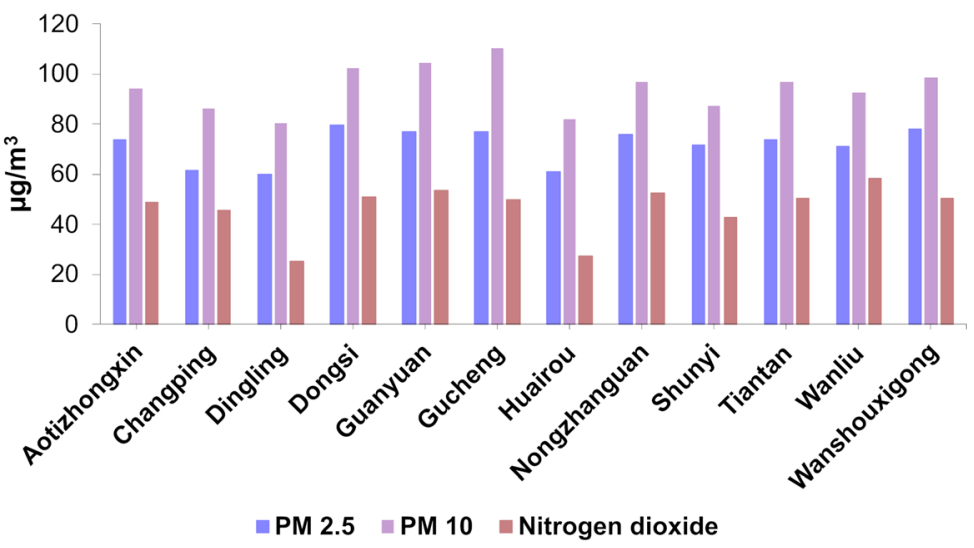

Fig. 1 Amount of PM2.5; PM10 and nitrogen dioxide in Wuhan (left) and in other cities of China (right) (data from https://www.kaggle.com/)

cities with lower average temperatures. In these cities, there was a substantial difference in the average number of people infected in April 2020 - during the first wave of the COVID19 pandemic, which was more than three times as high when compared with the relative number in cities with low levels of air pollution (Coccia 2021). As a matter of fact, the northern Italian regions most impacted by COVID-19 were also the ones presenting the highest PM10 and PM2.5 levels in Europe (Martelletti and Martelletti 2020; Conticini et al. 2020; Fattorini and Regoli 2020).

COVID-19 first spread to China, South Korea, and Iran, and then to Italy before the rest of Europe and the eastern USA, between latitude $30^{\circ}$ and $50^{\circ} \mathrm{North}$, in the winter period (precisely from December 2019 to April 2020), just when meteorological conditions, such as low temperature (between 5 and $11^{\circ} \mathrm{C}$ ) and low specific and absolute humidity of 3-6 $\mathrm{g} / \mathrm{kg}$ and $4-7 \mathrm{~g} / \mathrm{m}^{3}$ respectively, were propitious for the spread of a respiratory virus (Sajadi et al. 2020).

Moreover, a retrospective study on the link between air pollutants and meteorological variables with the COVID-19 occurrence demonstrated the relationship of some meteorological parameters, especially relative humidity with PM2.5 and COVID-19 in three Chinese cities: Wuhan, Xiaogan, and Huanggang (Jiang et al. 2020). Nevertheless, it is still unclear how the SARS-CoV-2 virus can propagate via PM2.5 particles (Jiang et al. 2020) although indoor air fine particulate matter (Fig. 2c, d, f, e) with a diameter of $\leq 2.5 \mu \mathrm{m}$ (PM2.5) has been reputed to be implicated as a transport agent for the virus (Nor et al. 2021).

\section{Pollution and susceptibility to viral insults}

The World Health Organization (WHO) reports that approximately a quarter of diseases are caused by exposure to environmental pollutants over time (GBD 2015 Risk Factors Collaborators 2016). These diseases include cardiovascular and chronic degenerative disorders, early deaths, and reproductive impairments (Cohen et al. 2005; Ji and Zhao 2015; GBD 2015 Risk Factors Collaborators 2016) together with lifestyle, as mentioned in the European Code against Cancer (Anderson et al. 2015). Furthermore, environmental pollutants have the potential to enhance susceptibility to non-communicable disease (NCD). The consequence of all this is a marked decline in the organism's defenses, which is probably attributable in part to trans-generational effects that may explain some of the worldwide disease burden of illness that comprises not only NCDs but also communicable diseases (Curley et al. 2011; Soubry et al. 2014; Braun and Champagne 2014; Anderson et al. 2015; Zhao et al. 2017; Horan et al. 2017; Bianco-Miotto et al. 2017; Suzuki 2018; Soubry 2018a, b; Xavier et al. 2019; Heindel 2019; Post et al. 2019). In addition, transgenerational effects have also been shown to include a reduction in the ability to defend against viral pathogens (Post et al. 2019). In the mouse model, recent studies have shown that chronic exposure to PM2.5 results in increased expression of the angiotensin-converting enzyme (Lin et al. 2018).

Besides, the chronic exposure to PM2.5 not only leads to inflammation in the alveolar district but also, after passing the alveolar barrier, arrives to the blood and then to the peripheral tissues, and induces oxidative stress both directly and via the response of the host to the chemical insult. This in turn induces inflammasome activation and, in particular, NLRP3, affecting the maturation and secretion of cytokines such as IL-1 beta and IL-18, both involved in the systemic inflammatory syndrome. Such conditions would promote the virulence of the pathogen, which includes vascular leakage and coagulopathy (Ghio et al. 2012; Li et al. 2019; Tsai et al. 2019; Caso et al. 2020).

The ability of SARS-CoV-2 to trigger a rapid autoimmune dysregulation process, results in the generation of a significant storm of cytokines, principally TNF- $\alpha$, IL- 6 , and IL- $1 \beta$, IL17 , IL-18, in individuals who are genetically predisposed (Masters et al. 2009). This process may become even more significant when preexisting environmental factors have previously altered mechanisms regulating cytokine release and/or 
Fig. 2 c Death mediated by indoor and outdoor air pollution worldwide. An air pollution color intensity illustrating the global death rate produced by indoor air pollution. The percentage displays the rate of death due to indoor air pollution in comparison to other diseases. $\mathbf{d}$ The number of indoor air pollution deaths in 1990 compared to 2017. e Death from indoor air pollution agedependent. Older people over 69 are at greater risk for indoor air pollution. $\mathbf{f}$ Rate of indoor air pollution per 100,000 people in 1990 compared to 2017 country distribution. Increasing indoor air pollution is a global concern (Source Institute for Health Metrics and Evaluation 2020 under creative common license attribution). Panels $\mathbf{c}, \mathbf{d}, \mathbf{f}$, and $\mathbf{e}$ were reused from Fig. 3 of Paital B, Agrawal PK. Air pollution by $\mathrm{NO} 2$ and PM2.5 explains COVID-19 infection severity by overexpression of angiotensinconverting enzyme 2 in respiratory cells: a review. Environ Chem Lett. 2020 Sep 18:1-18. doi: 10.1007/s10311-020-01091w obtained with License Number 4971970782195
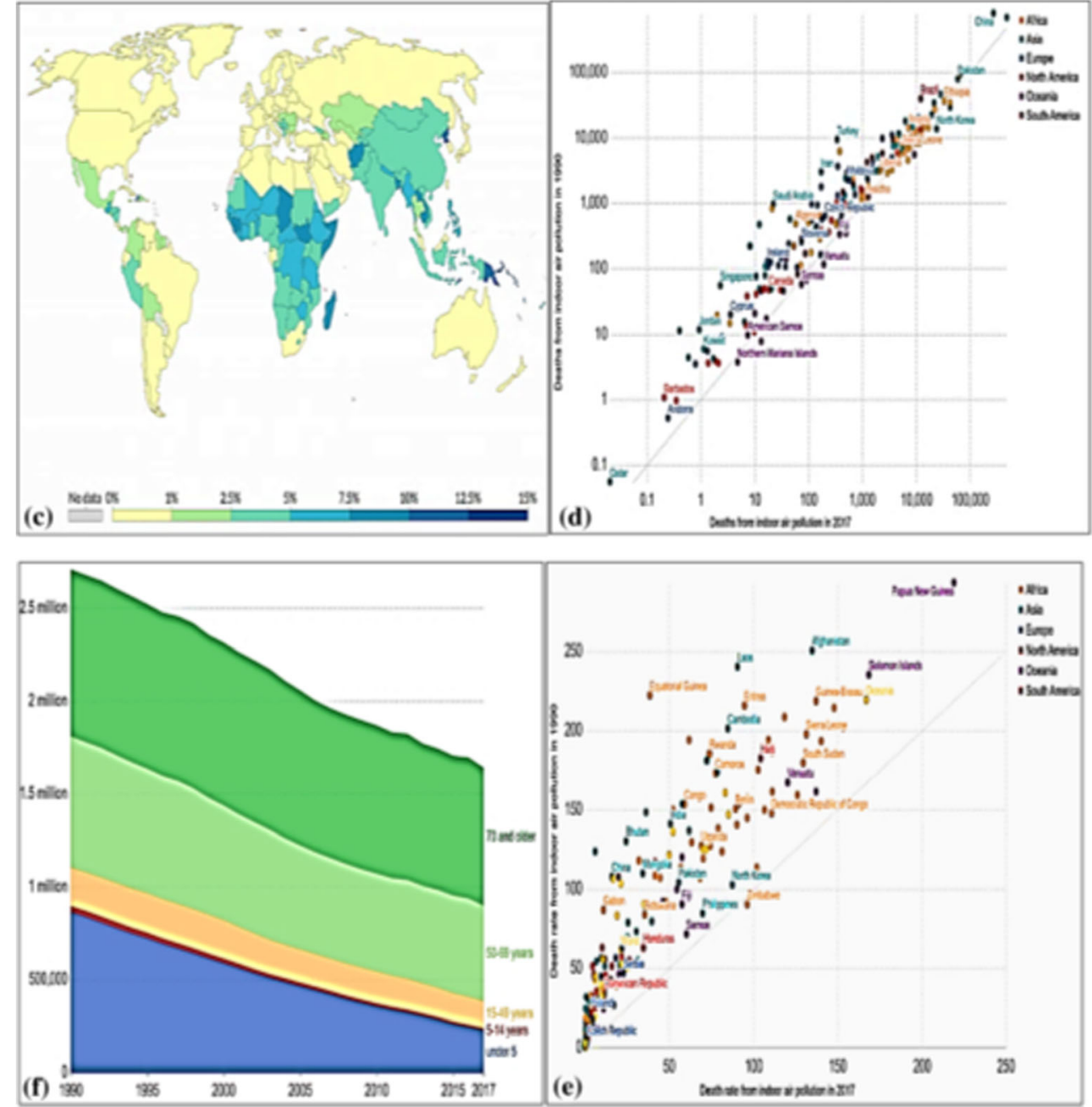

also when certain polymorphisms for IL-6 are present, such as among specific populations or ethnic groups that would render them more prone to virus complications (El-Maadawy et al. 2019). To be precise, all populations are susceptible to COVID-19, but the people most susceptible to complications of this disease turn out to be the elderly, individuals with chronic diseases, or low immunity, pregnant women, and newborns (Working Group for the Prevention and Control of Neonatal 2019-nCoV Infection in the Perinatal Period of the Editorial Committee of Chinese Journal of Contemporary Pediatrics 2020; Huang et al. 2020; Chen et al. 2020).

In addition to this, it should be added that, air pollutants represent a potential co-factor of major damage because they are capable of inducing oxidative stress, inflammatory processes, immune imbalance, and coagulation at the systemic level. All these effects, consequently, make the organism susceptible to complications from pathogens, including SARSCoV-2 (Glencross et al. 2020).

This situation is still more real in those areas of the world where a very poor air quality, reducing the antioxidant, and immune defenses of the body, could promote viral contagion and/or increased virulence. This is so true that, as well described by the Paital and Agrawal 2020 studies, the overall mortality rate (\%) from air pollution is higher than for other diseases as can be well understood from Fig. 3 which shows the world map of tropospheric NO2 concentrations from the Sentinel-5P satellite (2018) (Fig. 3a) and the world map of global mortality rates (\%) from air pollution relative to other diseases (Fig. 3b) (Paital and Agrawal 2020).

Interestingly, $\mathrm{NO} 2$ is also potent in inducing upregulation of the ACE- 2 enzyme and a positive correlation between NO2 and COVID-19 has been observed in countries such as Europe: France, Italy, Spain, and Germany (Ogen 2020), coherently with Fig. 3a. SARS-CoV-2 can interact with the renin-angiotensin-aldosterone system (RAAS) through ACE-2 (Ogen 2020). The RAAS is a hormonal system that controls blood pressure and fluid and electrolyte balance, and also systemic vascular resistance (Fountain and Lappin 2020). 


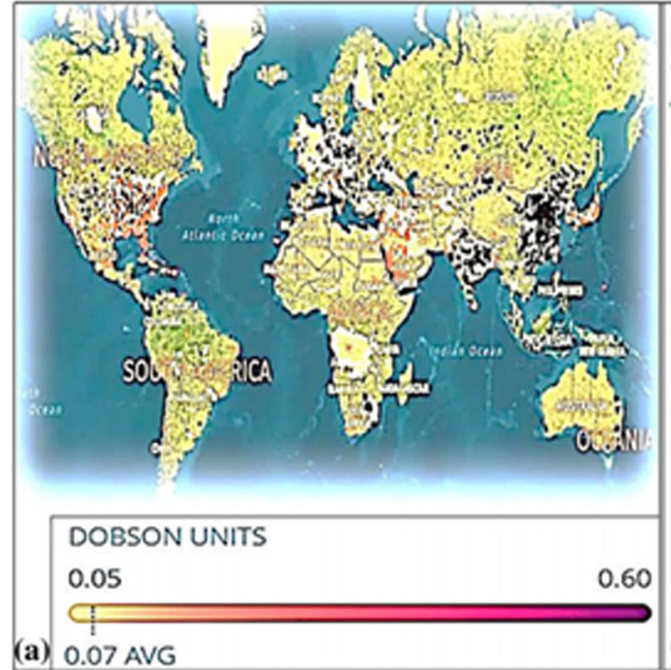

Fig. 3 Panel a shows the world map of tropospheric NO2 concentrations from the Sentinel-5P satellite (2018). The values were measured daily for 90 days, from June to August 2018 (Chow 2020; Environmental Protection Agency, 2020, Myllyvirta and Howard 2020) (a). Panel b shows instead the world global death rate $(\%)$ by air pollution map in comparison with other diseases. Color intensity illustrating the global

\section{Sperm decline in polluted areas}

Several data have indicated that there has been a decline in sperm parameters in several areas of the world over the past four decades. This decline has been particularly notable in those areas of strong industrial development that had high levels of air pollution (Mann et al. 2020). This is well described in Fig. 4 showing the decline in sperm concentration (million $/ \mathrm{mL}$ ) that occurred in North America, South America, Europe, Asia, and Africa, from 1980/85 to 2010/15 (Agarwal et al. 2015). As shown in the figure, the average decrease in sperm concentration worldwide during those years was about $57 \%$.

In addition, there is a systematic review and metaregression analysis in the literature reporting a $59.3 \%$ decline in total sperm count in Europe, the USA, Canada, and New

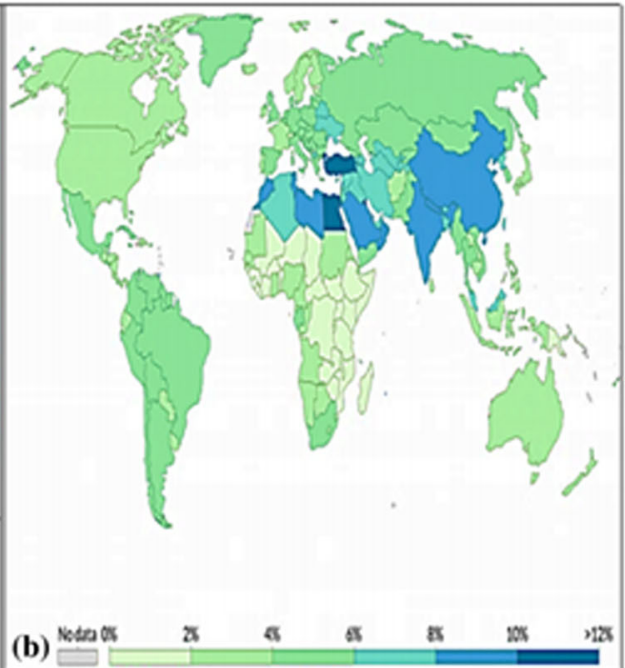

mortality rate due to air pollution (b). Panels $\mathbf{a}$ and $\mathbf{b}$ were reused from Fig. 3 of Paital B, Agrawal PK. Air pollution by NO2 and PM2.5 explains COVID-19 infection severity by overexpression of angiotensinconverting enzyme 2 in respiratory cells: a review. Environ Chem Lett. 2020 Sep 18:1-18. doi: 10.1007/s10311-020-01091-w obtained with License Number 4971970782195

Zealand considering the years from 1971 to 2011 (Levine et al. 2017). In Asia, over the past 20 years, there has been a $20 \%$ increase in the infertility rate of Iranian men while in China, a study that considered a total of 30,636 young donors, showed that sperm concentration had decreased from $68 \times$ $106 / \mathrm{mL}$ to $47 \times 106 / \mathrm{mL}$, while the percentage of spermatozoa presenting normal morphology was reduced from 31.8 to 10.8\% (Safarinejad 2008; Huang et al. 2017). A decline in sperm count has also been recorded in Brazil, where, over the past 23 years, there has been an average sperm reduction of 0.24 million $/ \mathrm{mL}$ per year (Siqueira et al. 2020).

The male reproductive system is particularly sensitive to environmental pollutants and chronic exposure to high levels of PM10, PM2.5, and to individual air pollutants such as NO2 and sulfur dioxide (SO2) negatively impacts sperm count, motility, and testicular volume (Zhang et al. 2020). The
Fig. 4 The figure shows the decrease of the sperm concentration (million $/ \mathrm{mL}$ ) observed in North America, South America, Europe, Asia, and Africa from $1980 / 85$ to $2010 / 15$ (Agarwal et al. 2015). The mean decrease of the sperm concentration in the word in those years has been about $57 \%$

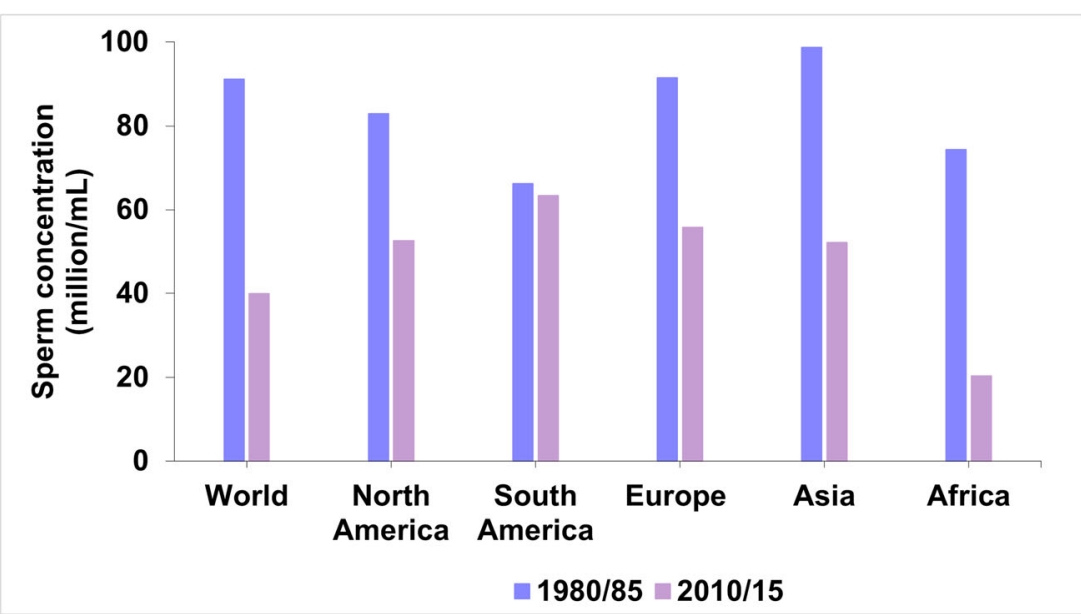


mechanisms of damage to spermatogenesis caused by environmental agents are still largely unknown, although the imbalance of oxygen radical species (ROS) and the resulting oxidative stress may represent the common denominator by which pollutants alter seminal parameters such as sperm count, motility, morphology, and especially the integrity of sperm DNA (Bosco et al. 2018; Jurewicz et al. 2018; Nowicka-Bauer and Nixon 2020). In addition, a very interesting review has recently been published that provides the current state of knowledge on the impact of a wide range of environmental stressors on several parameters used to estimate and assess gamete quality in humans and in the main animal models that are used for experimental research. In particular, this review examines the effects of metals, biocides, herbicides, nanoparticles, plastics, temperature rise, ocean acidification, air pollution, and lifestyle on the physiological parameters that underlie gamete fertilization competence. This review strongly emphasizes the concept that environmental stressors pose a serious threat to gamete quality with reproductive disorders and failure of the living organism (Gallo et al. 2020). Moreover, compared to oocytes, spermatozoa are very sensitive to the pro-oxidant effects of environmental pollutants. The reason for this lies in the fact that these cells have a limited volume of cytoplasmic space, with less antioxidant defense, and in addition the lipids of the sperm membrane are the target of ROS (Aitken et al. 2016). Male gametes are also the most sensitive cells to the accumulation of damaged DNA so in our research we have investigated to try to understand the reasons. Through molecular investigations, we have recently shown that sperm nuclear basic proteins (SNBP) from samples of men living in polluted areas have a novel and unexpected behavior, being involved in oxidative DNA damage (Lettieri et al. 2020a). Furthermore, we have also reported preliminary results that appear to indicate transgenerational effects of pollutants on molecular alterations in SNBPs in humans living in polluted areas (Lettieri et al. 2020b). These data are in line with those obtained in mice, in which has been demonstrated that the susceptibility to certain pollutants increases across generations (Horan et al. 2017). The negative trend in sperm quality in conjunction with annual high average levels of PM10, PM2.5, and NO2, could suggest that sperm decline may be the first clinical sign of environmental pressure and that semen quality could be a potential indicator of susceptibility to insults in polluted areas including viral infections as described in the following section.

\section{Human semen as environmental and health marker}

The sperm chromatin structure is often impaired, largely due to oxidative damage. As a matter of fact, many pollutants, including heavy metals, cause molecular genotoxic effects and induce alterations in chromatin remodeling. Specifically, multiple histone sites, depending on heavy metal coordination within the nucleosome, may represent active sources of ROS generated in DNA proximity (Mohideen et al. 2010). Some marine organisms and plants are extensively used as bioindicators of environmental pollution (Basile et al. 2017; Maresca et al. 2018, 2020). In this regard, we have recently provided new insights on some metals toxicity mechanisms in marine organisms (Piscopo et al. 2018a, b, c; De Guglielmo et al. 2019; Lettieri et al. 2019).

Our knowledge regarding the molecular mechanisms underlying the toxicity of metals on the reproductive health of marine organisms, gained through studies of these organisms, has been useful in understanding the role of pollutants on human reproductive health. Our studies on individuals living in polluted areas demonstrated that also human semen could be considered an ideal early sentinel with a double function: environmental and human health (Lettieri et al. 2020a, b). Other authors besides us point to human semen as a "sentinel biomarker" of subclinical biological effect suitable for monitoring the impact of adverse environmental exposures (Nordkap et al. 2012; Bergamo et al. 2016; Montano et al. 2017).

Semen quality has also been found to reflect individuals' general health condition, as recent studies had shown an association between semen quality and the onset of chronic diseases, with male infertility being a predictor of future hospitalization and overall mortality (Jensen et al. 2009; Eisenberg et al. 2015; Pisarska 2017; Choy and Eisenberg 2018).

We assume that these observations could support the comprehension of the dynamics that may have been involved in the facilitation of COVID-19 severity in polluted areas. As an early and responsive environmental and health marker, semen quality could be used as a key indicator of sensitivity to environmental health hazards in the general population and be utilized for health risk management, innovative prevention programs, and health surveillance, especially in heavily polluted areas. However, although factors such as high population density, climatic characteristics, age, comorbidity, different health systems' ability to respond to the pandemic, and the prevention policies employed in different countries presently play a pivotal role, we should not underestimate the possible facilitatory role of pollution in augmenting the risk of contracting COVID-19 for people living in areas with greater environmental impact.

In addition, there is also evidence that these same areas have a greater incidence of NCD and male infertility due to a complex interrelationship of chronic chemical and physical exposure factors, in conjunction with the contribution of lifestyle behavioral risk factors and the genetic background of individuals. In addition, exposure to heavy metals such as $\mathrm{As}, \mathrm{Cd}, \mathrm{Hg}$, and $\mathrm{Pb}$ has also been shown to be linked to respiratory dysfunction and disease (Skalny et al. 2021). Of course, this evidence is supportive in explaining the role of 
heavy metal exposure in compromised mucociliary clearance, diminished barrier function, respiratory tract inflammation, oxidative stress, and apoptosis. Moreover, an association has also been provided between heavy metal exposure and the severity of viral diseases, including influenza and respiratory syncytial virus (Skalny et al. 2021). The latter may be considered a result of the adverse effects of metal exposure on adaptive immunity. Thus, early signs of damage to organ-sentinel systems such as the male reproductive system and the decline in human sperm quality observed in recent decades may hint at how relevant environmental pressures may be and how increasingly unsustainable it is becoming. Finally, through the use of human semen, as an early sentinel of environmental and general human health status, we could have an opportunity to know the population health status in a given environmental context and go to predict both the susceptibility to the virus impact and the medium and long-term negative effects on human health.

\section{Conclusion}

A robust body of experimental evidence suggests that pollution should be recognized as an important cofactor for increased transmission and severity of SARS-CoV-2 infection outcomes and mortality. It was therefore interesting to learn of the significant reduction in $\mathrm{NO} 2, \mathrm{CO} 2$, and $\mathrm{O} 3$ as a result of the decrease in human activities during the SARS-CoV-2 outbreak in northeast China (epicenter of the COVID-19 pandemic onset) known to be affected by this massive increase in carbon emissions due mostly to transport (Dutheil et al. 2020a, b; Wang et al. 2020). Thus, in the extremely dramatic context of the SARS-CoV-2 pandemic, this overall decrease of atmospheric pollution has offered a very strong signal for the conservation of our environment and some related cardiovascular and respiratory diseases (Guan et al. 2016; Cramer et al. 2020). We also believe that semen quality used as an early environmental and health marker could help policy makers to promptly intervene in areas with significant environmental criticality to abate air, water, and soil pollution with an integrated One Health approach, where information sharing among diverse and key professionals (clinicians, biologists, chemists, virologists, veterinarians, economists, epidemiologists) could be successful in establishing a systemic approach that could be efficient and beneficial on a global scale (Mackenzie and Jeggo 2019). Above all, it is essential to evaluate the effectiveness of the measures adopted to safeguard the community's health and also its social and productive organization, with the objective of avoiding, or at least limiting, the rapid and destructive spread of future viruses.

Author contributions LM developed the concept. LM, IMB, and MP wrote the initial draft the manuscript; PMB collected the data; GL and
MP prepared the figures. IMB and MP performed the literature review and improved the manuscript. LM, IMB, AG, FD, GL, OM, and MP significantly reviewed and critically revised the paper; LM, IMB, FD, PMB, GL, AG, OM, and MP approved the final version of the manuscript.

Funding Open access funding provided by Università degli Studi di Napoli Federico II within the CRUI-CARE Agreement. The authors declare that they have not received external fund to those of departmental research.

Data availability The authors declare to acquire the permission for use of Figs. 2 and 3. Air pollution by NO2 and PM2.5 explains COVID-19 infection severity by overexpression of angiotensin-converting enzyme 2 in respiratory cells: a review. Environ Chem Lett. 2020 Sep 18:1-18. doi: 10.1007/s10311-020-01091-w obtained with License Number 4971970782195.

\section{Declarations}

Ethics approval and consent to participate Not applicable.

Consent for publication Not applicable.

Competing interests The authors declare no competing interest, not financial and not personal.

Open Access This article is licensed under a Creative Commons Attribution 4.0 International License, which permits use, sharing, adaptation, distribution and reproduction in any medium or format, as long as you give appropriate credit to the original author(s) and the source, provide a link to the Creative Commons licence, and indicate if changes were made. The images or other third party material in this article are included in the article's Creative Commons licence, unless indicated otherwise in a credit line to the material. If material is not included in the article's Creative Commons licence and your intended use is not permitted by statutory regulation or exceeds the permitted use, you will need to obtain permission directly from the copyright holder. To view a copy of this licence, visit http://creativecommons.org/licenses/by/4.0/.

\section{References}

Agarwal A, Mulgund A, Hamada A, Chyatte MR (2015) A unique view on male infertility around the globe. Reprod Biol Endocrinol 13:37. https://doi.org/10.1186/s12958-015-0032-1

Aitken RJ, Gibb Z, Baker MA, Drevet J, Gharagozloo P (2016) Causes and consequences of oxidative stress in spermatozoa. Reprod Fertil Dev 28:1-10. https://doi.org/10.1071/RD15325

Anderson AS, Key TJ, Norat T, Scoccianti C, Cecchini M, Berrino F, Boutron-Ruault MC, Espina C, Leitzmann M, Powers H, Wiseman M, Romieu I (2015) European code against cancer 4th edition: obesity, body fatness and cancer. Cancer Epidemiol 39(Suppl 1):S34 S45. https://doi.org/10.1016/j.canep.2015.01.017

Basile A, Loppi S, Piscopo M, Paoli L, Vannini A, Monaci F, Sorbo S, Lentini M, Esposito S (2017) The biological response chain to pollution: a case study from the "Italian Triangle of Death" assessed with the liverwort Lunularia cruciata. Environ Sci Pollut Res Int 24: 26185-26193. https://doi.org/10.1007/s11356-017-9304-y

Beloconi A, Chrysoulakis N, Lyapustin A, Utzinger J, Vounatsou P (2018) Bayesian geostatistical modelling of PM10 and PM2.5 surface level concentrations in Europe using high-resolution satellite- 
derived products. Environ Int 121:57-70. https://doi.org/10.1016/j. envint.2018.08.041

Bergamo P, Volpe MG, Lorenzetti S, Mantovani A, Notari T, Cocca E, Cerullo S, di Stasio M, Cerino P, Montano L (2016) Human semen as an early, sensitive biomarker of highly polluted living environment in healthy men: a pilot biomonitoring study on trace elements in blood and semen and their relationship with sperm quality and RedOx status. Reprod Toxicol 66:1-9. https://doi.org/10.1016/j. reprotox.2016.07.018

Bianco-Miotto T, Craig JM, Gasser YP, van Dijk SJ, Ozanne SE (2017) Epigenetics and DOHaD: from basics to birth and beyond. J Dev Orig Health Dis 8:513-519. https://doi.org/10.1017/ S2040174417000733

Bosco L, Notari T, Ruvolo G, Roccheri MC, Martino C, Chiappetta R, Carone D, Lo Bosco G, Carrillo L, Raimondo S, Guglielmino A, Montano L (2018) Sperm DNA fragmentation: an early and reliable marker of air pollution. Environ Toxicol Pharmacol 58:243-249. https://doi.org/10.1016/j.etap.2018.02.001

Braun K, Champagne FA (2014) Paternal influences on offspring development: behavioural and epigenetic pathways. J Neuroendocrinol 26:697-706. https://doi.org/10.1111/jne.12174

Caso F, Costa L, Ruscitti P, Navarini L, del Puente A, Giacomelli R, Scarpa R (2020) Could Sars-coronavirus-2 trigger autoimmune and/or autoinflammatory mechanisms in genetically predisposed subjects? Autoimmun Rev 19:102524. https://doi.org/10.1016/j. autrev.2020.102524

Chavarria-Miró G, Anfruns-Estrada E, Guix S et al (2020) Sentinel surveillance of SARS-CoV-2 in wastewater anticipates the occurrence of COVID-19 cases. Epidemiology. https://doi.org/10.1101/2020. 06.13.20129627

Chen H, Guo J, Wang C, Luo F, Yu X, Zhang W, Li J, Zhao D, Xu D, Gong Q, Liao J, Yang H, Hou W, Zhang Y (2020) Clinical characteristics and intrauterine vertical transmission potential of COVID19 infection in nine pregnant women: a retrospective review of medical records. Lancet 395:809-815. https://doi.org/10.1016/ S0140-6736(20)30360-3

Chow L (2020) World's Biggest NO2 Emissions Hotspots Revealed Available online: https://www.ecowatch.com/worlds-biggest-no2emissionshotspots-2616234815.html. Accessed 28 May 2021

Choy JT, Eisenberg ML (2018) Male infertility as a window to health. Fertil Steril 110:810-814. https://doi.org/10.1016/j.fertnstert.2018. 08.015

Coccia M (2021) Effects of the spread of COVID-19 on public health of polluted cities: results of the first wave for explaining the dejà vu in the second wave of COVID-19 pandemic and epidemics of future vital agents. Environ Sci Pollut Res Int 28:19147-19154. https://doi. org/10.1007/s11356-020-11662-7

Cohen AJ, Ross Anderson H, Ostro B, Pandey KD, Krzyzanowski M, Künzli N, Gutschmidt K, Pope A, Romieu I, Samet JM, Smith K (2005) The global burden of disease due to outdoor air pollution. J Toxicol Environ Health A 68:1301-1307. https://doi.org/10.1080/ 15287390590936166

Conticini E, Frediani B, Caro D (2020) Can atmospheric pollution be considered a co-factor in extremely high level of SARS-CoV-2 lethality in Northern Italy? Environ Pollut 261:114465. https://doi. org/10.1016/j.envpol.2020.114465

Cramer J, Jørgensen JT, Hoffmann B, Loft S, Bräuner EV, Prescott E, Ketzel M, Hertel O, Brandt J, Jensen SS, Backalarz C, Simonsen MK, Andersen ZJ (2020) Long-term exposure to air pollution and incidence of myocardial infarction: a Danish nurse cohort study. Environ Health Perspect 128:57003. https://doi.org/10.1289/ EHP5818

Cui Y, Zhang Z-F, Froines J, Zhao J, Wang H, Yu SZ, Detels R (2003) Air pollution and case fatality of SARS in the People's Republic of China: an ecologic study. Environ Health 2:15. https://oi.org/10. 1186/1476-069X-2-15
Curley JP, Mashoodh R, Champagne FA (2011) Epigenetics and the origins of paternal effects. Horm Behav 59:306-314. https://doi. org/10.1016/j.yhbeh.2010.06.018

De Guglielmo V, Puoti R, Notariale R et al (2019) Alterations in the properties of sperm protamine-like II protein after exposure of Mytilus galloprovincialis (Lamarck 1819) to sub-toxic doses of cadmium. Ecotoxicol Environ Saf 169:600-606. https://doi.org/10. 1016/j.ecoenv.2018.11.069

Deslandes A, Berti V, Tandjaoui-Lambotte Y, Alloui C, Carbonnelle E, Zahar JR, Brichler S, Cohen Y (2020) SARS-CoV-2 was already spreading in France in late December 2019. Int J Antimicrob Agents 55:106006. https://doi.org/10.1016/j.ijantimicag.2020.106006

Domingo JL, Rovira J (2020) Effects of air pollutants on the transmission and severity of respiratory viral infections. Environ Res 187: 109650. https://doi.org/10.1016/j.envres.2020.109650

Dutheil F, Baker JS, Navel V (2020a) COVID-19 as a factor influencing air pollution? Environ Pollut 263:114466. https://doi.org/10.1016/j. envpol.2020.114466

Dutheil F, Baker JS, Navel V (2020b) COVID-19 and air pollution: the worst is yet to come. Environ Sci Pollut Res 27:44647-44649. https://doi.org/10.1007/s11356-020-11075-6

Eisenberg ML, Li S, Behr B, Pera RR, Cullen MR (2015) Relationship between semen production and medical comorbidity. Fertil Steril 103:66-71. https://doi.org/10.1016/j.fertnstert.2014.10.017

El-Maadawy EA, Talaat RM, Ahmed MM, El-Shenawy SZ (2019) Interleukin-6 promotor gene polymorphisms and susceptibility to chronic hepatitis B virus in Egyptians. Hum Immunol 80:208214. https://doi.org/10.1016/j.humimm.2018.12.009

Fattorini D, Regoli F (2020) Role of the chronic air pollution levels in the Covid-19 outbreak risk in Italy. Environ Pollut 264:114732. https:// doi.org/10.1016/j.envpol.2020.114732

Fountain JH, Lappin SL (2020) Physiology, renin angiotensin system. In: StatPearls. StatPearls Publishing, Treasure Island

Gallo A, Boni R, Tosti E (2020) Gamete quality in a multistressor environment. Environ Int 138:105627. https://doi.org/10.1016/j.envint. 2020.105627

GBD 2015 Risk Factors Collaborators (2016) Global, regional, and national comparative risk assessment of 79 behavioural, environmental and occupational, and metabolic risks or clusters of risks, 19902015: a systematic analysis for the Global Burden of Disease Study 2015. Lancet 388:1659-1724. https://doi.org/10.1016/ S0140-6736(16)31679-8

Ghio AJ, Carraway MS, Madden MC (2012) Composition of air pollution particles and oxidative stress in cells, tissues, and living systems. J Toxicol Environ Health B Crit Rev 15:1-21. https://doi.org/ 10.1080/10937404.2012.632359

Glencross DA, Ho T-R, Camiña N, Hawrylowicz CM, Pfeffer PE (2020) Air pollution and its effects on the immune system. Free Radic Biol Med 151:56-68. https://doi.org/10.1016/j.freeradbiomed.2020.01. 179

Guan W-J, Zheng X-Y, Chung KF, Zhong N-S (2016) Impact of air pollution on the burden of chronic respiratory diseases in China: time for urgent action. Lancet 388:1939-1951. https://doi.org/10. 1016/S0140-6736(16)31597-5

Heindel JJ (2019) The developmental basis of disease: update on environmental exposures and animal models. Basic Clin Pharmacol Toxicol 125(Suppl 3):5-13. https://doi.org/10.1111/bcpt.13118

Holme JA, Låg M, Øvrevik J, Golestani K (2020) Can air pollution increase the risk of COVID-19? Tidsskr Nor Laegeforen 140. https://doi.org/10.4045/tidsskr.20.0843

Horan TS, Marre A, Hassold T, Lawson C, Hunt PA (2017) Germline and reproductive tract effects intensify in male mice with successive generations of estrogenic exposure. PLoS Genet 13:e1006885. https://doi.org/10.1371/journal.pgen.1006885

Huang C, Li B, Xu K, Liu D, Hu J, Yang Y, Nie HC, Fan L, Zhu W (2017) Decline in semen quality among 30,636 young Chinese men 
from 2001 to 2015. Fertil Steril 107:83-88.e2. https://doi.org/10. 1016/j.fertnstert.2016.09.035

Huang C, Wang Y, Li X, Ren L, Zhao J, Hu Y, Zhang L, Fan G, Xu J, Gu X, Cheng Z, Yu T, Xia J, Wei Y, Wu W, Xie X, Yin W, Li H, Liu M, Xiao Y, Gao H, Guo L, Xie J, Wang G, Jiang R, Gao Z, Jin Q, Wang J, Cao B (2020) Clinical features of patients infected with 2019 novel coronavirus in Wuhan, China. Lancet 395:497-506. https://doi.org/10.1016/S0140-6736(20)30183-5

Jensen TK, Jacobsen R, Christensen K, Nielsen NC, Bostofte E (2009) Good semen quality and life expectancy: a cohort study of 43,277 men. Am J Epidemiol 170:559-565. https://doi.org/10.1093/aje/ kwp168

Ji W, Zhao B (2015) Estimating mortality derived from indoor exposure to particles of outdoor origin. PLoS One 10. https://doi.org/10.1371/ journal.pone. 0124238

Jiang Y, Wu X-J, Guan Y-J (2020) Effect of ambient air pollutants and meteorological variables on COVID-19 incidence. Infect Control Hosp Epidemiol 41:1011-1015. https://doi.org/10.1017/ice.2020. 222

Jurewicz J, Dziewirska E, Radwan M, Hanke W (2018) Air pollution from natural and anthropic sources and male fertility. Reprod Biol Endocrinol 16:109. https://doi.org/10.1186/s12958-018-0430-2

Karan A, Ali K, Teelucksingh S, Sakhamuri S (2020) The impact of air pollution on the incidence and mortality of COVID-19. Glob Health Res Policy 5:39. https://doi.org/10.1186/s41256-020-00167-y

Lettieri G, Mollo V, Ambrosino A, Caccavale F, Troisi J, Febbraio F, Piscopo M (2019) Molecular effects of copper on the reproductive system of Mytilus galloprovincialis. Mol Reprod Dev 86:13571368. https://doi.org/10.1002/mrd.23114

Lettieri G, D'Agostino G, Mele E, Cardito C, Esposito R, Cimmino A, Giarra A, Trifuoggi M, Raimondo S, Notari T, Febbraio F, Montano L, Piscopo M (2020a) Discovery of the involvement in DNA oxidative damage of human sperm nuclear basic proteins of healthy young men living in polluted areas. Int J Mol Sci 21. https://doi. org/10.3390/ijms21124198

Lettieri G, Marra F, Moriello C, Prisco M, Notari T, Trifuoggi M, Giarra A, Bosco L, Montano L, Piscopo M (2020b) Molecular alterations in Spermatozoa of a family case living in the land of fires. A first look at possible transgenerational effects of pollutants. Int J Mol Sci 21. https://doi.org/10.3390/ijms 21186710

Levine H, Jørgensen N, Martino-Andrade A, Mendiola J, Weksler-Derri D, Mindlis I, Pinotti R, Swan SH (2017) Temporal trends in sperm count: a systematic review and meta-regression analysis. Hum Reprod Update 23:646-659. https://doi.org/10.1093/humupd/ dmx022

Li Y, Hu C, Wang P, Liu Y, Wang L, Pi Q, Gong Z, Yang X, Mak M, Wu $Y$ (2019) Indoor nanoscale particulate matter-induced coagulation abnormality based on a human 3D microvascular model on a microfluidic chip. J Nanobiotechnology 17:20. https://doi.org/10. 1186/s12951-019-0458-2

Lin C-I, Tsai C-H, Sun Y-L, Hsieh WY, Lin YC, Chen CY, Lin CS (2018) Instillation of particulate matter 2.5 induced acute lung injury and attenuated the injury recovery in ACE2 knockout mice. Int J Biol Sci 14:253-265. https://doi.org/10.7150/ijbs.23489

Mackenzie JS, Jeggo M (2019) The one health approach-why is it so important? Trop Med Infect Dis 4. https://doi.org/10.3390/ tropicalmed 4020088

Mann U, Shiff B, Patel P (2020) Reasons for worldwide decline in male fertility. Curr Opin Urol 30:296-301. https://doi.org/10.1097/MOU. 0000000000000745

Maresca V, Fusaro L, Sorbo S, Siciliano A, Loppi S, Paoli L, Monaci F, karam EA, Piscopo M, Guida M, Galdiero E, Insolvibile M, Basile A (2018) Functional and structural biomarkers to monitor heavy metal pollution of one of the most contaminated freshwater sites in Southern Europe. Ecotoxicol Environ Saf 163:665-673. https://doi. org/10.1016/j.ecoenv.2018.07.122
Maresca V, Lettieri G, Sorbo S, Piscopo M, Basile A (2020) Biological responses to cadmium stress in liverwort Conocephalum conicum (Marchantiales). Int J Mol Sci 21. https://doi.org/10.3390/ ijms 21186485

Martelletti L, Martelletti P (2020) Air pollution and the novel Covid-19 disease: a putative disease risk factor. SN Compr Clin Med 2:1-5. https://doi.org/10.1007/s42399-020-00274-4

Masters SL, Simon A, Aksentijevich I, Kastner DL (2009) Horror autoinflammaticus: the molecular pathophysiology of autoinflammatory disease. Annu Rev Immunol 27:621-668. https://doi.org/10.1146/annurev.immunol.25.022106.141627

Mohideen K, Muhammad R, Davey CA (2010) Perturbations in nucleosome structure from heavy metal association. Nucleic Acids Res 38: 6301-6311. https://doi.org/10.1093/nar/gkq420

Montano L, Bergamo P, Andreassi MG, Vecoli C, Volpe MG, Lorenzetti S, Mantovani A, Notari T (2017) The role of human semen for assessing environmental impact on human health in risk areas: novels and early biomarkers of environmental pollution. EcoFoodFertility project. Reprod Toxicol 72:44-45. https://doi. org/10.1016/j.reprotox.2017.06.169

Myllyvirta L, Howard E (2020) Mapped: Nitrogen Dioxide Pollution around the World Available online: https://unearthed.greenpeace. org/2018/10/29/nitrogen-dioxide-no2-pollution-world-map/. Accessed 28 May 2021

Nor NSM, Yip CW, Ibrahim N, Jaafar MH, Rashid ZZ, Mustafa N, Hamid HHA, Chandru K, Latif MT, Saw PE, Lin CY, Alhasa KM, Hashim JH, Nadzir MSM (2021) Particulate matter (PM2.5) as a potential SARS-CoV-2 carrier. Sci Rep 11:2508. https://doi.org/ 10.1038/s41598-021-81935-9

Nordkap L, Joensen UN, Blomberg Jensen M, Jørgensen N (2012) Regional differences and temporal trends in male reproductive health disorders: semen quality may be a sensitive marker of environmental exposures. Mol Cell Endocrinol 355:221-230. https:// doi.org/10.1016/j.mce.2011.05.048

Nowicka-Bauer K, Nixon B (2020) Molecular changes induced by oxidative stress that impair human sperm motility. Antioxidants (Basel) 9. https://doi.org/10.3390/antiox9020134

Ogen Y (2020) Assessing nitrogen dioxide (NO2) levels as a contributing factor to coronavirus (COVID-19) fatality. Sci Total Environ 726: 138605. https://doi.org/10.1016/j.scitotenv.2020.138605

Paital B, Agrawal PK (2020) Air pollution by NO2 and PM2.5 explains COVID-19 infection severity by overexpression of angiotensinconverting enzyme 2 in respiratory cells: a review. Environ Chem Lett 19:25-42. https://doi.org/10.1007/s10311-020-01091-w

Pansini R, Fornacca D (2020a) Early evidence of a higher incidence of COVID-19 in the air-polluted regions of eight severely affected countries. medRxiv 2020.04.30.20086496. https://doi.org/10.1101/ 2020.04.30.20086496

Pansini R, Fornacca D (2020b) Initial evidence of higher morbidity and mortality due to SARS-CoV-2 in regions with lower air quality. 17

Pisarska MD (2017) Fertility status and overall health. Semin Reprod Med 35:203-204. https://doi.org/10.1055/s-0037-1603728

Piscopo M, Notariale R, Rabbito D, Ausió J, Olanrewaju OS, Guerriero G (2018a) Mytilus galloprovincialis (Lamarck, 1819) spermatozoa: hsp70 expression and protamine-like protein property studies. Environ Sci Pollut Res Int 25:12957-12966. https://oi.org/10. 1007/s11356-018-1570-9

Piscopo M, Trifuoggi M, Notariale R et al (2018b) Protamine-like proteins' analysis as an emerging biotechnique for cadmium impact assessment on male mollusk Mytilus galloprovincialis (Lamarck 1819). Acta Biochim Pol 65:259-267. https://doi.org/10.18388/ abp.2017_2533

Piscopo M, Trifuoggi M, Scarano C, Gori C, Giarra A, Febbraio F (2018c) Relevance of arginine residues in $\mathrm{Cu}(\mathrm{II})$-induced DNA breakage and Proteinase K resistance of $\mathrm{H} 1$ histones. Sci Rep 8: 7414. https://doi.org/10.1038/s41598-018-25784-z 
Post CM, Boule LA, Burke CG, O'Dell CT, Winans B, Lawrence BP (2019) The ancestral environment shapes antiviral CD8+ T cell responses across generations. iScience 20:168-183. https://doi.org/10. 1016/j.isci.2019.09.014

Pozzer A, Dominici F, Haines A, Witt C, Münzel T, Lelieveld J (2020) Regional and global contributions of air pollution to risk of death from COVID-19. Cardiovasc Res 116:2247-2253. https://doi.org/ $10.1093 / \mathrm{cvr} / \mathrm{cvaa} 288$

Safarinejad MR (2008) Infertility among couples in a population-based study in Iran: prevalence and associated risk factors. Int J Androl 31: 303-314. https://doi.org/10.1111/j.1365-2605.2007.00764.x

Sajadi MM, Habibzadeh P, Vintzileos A, Shokouhi S, Miralles-Wilhelm F, Amoroso A (2020) Temperature, humidity, and latitude analysis to estimate potential spread and seasonality of coronavirus disease 2019 (COVID-19). JAMA Netw Open 3:e2011834. https://doi.org/ 10.1001/jamanetworkopen.2020.11834

Siqueira S, Ropelle AC, Nascimento JAA, Fazano FAT, Bahamondes LG, Gabiatti JR, Costa-Paiva L, Baccaro LF (2020) Changes in seminal parameters among Brazilian men between 1995 and 2018. Sci Rep 10:6430. https://doi.org/10.1038/s41598-020-63468-9

Skalny AV, Lima TRR, Ke T, Zhou JC, Bornhorst J, Alekseenko SI, Aaseth J, Anesti O, Sarigiannis DA, Tsatsakis A, Aschner M, Tinkov AA (2021) Corrigendum to "Toxic metal exposure as a possible risk factor for COVID-19 and other respiratory infectious diseases" [Food Chem. Toxicol. 146 111809]. Food Chem Toxicol 149:111999. https://doi.org/10.1016/j.fct.2021.111999

Skirienė AF, Stasiškienẻ Ž (2021) COVID-19 and air pollution: measuring pandemic impact to air quality in five European countries. Atmosphere 12:290. https://doi.org/10.3390/atmos12030290

Soubry A (2018a) Epigenetics as a driver of developmental origins of health and disease: did we forget the fathers? Bioessays 40. https:// doi.org/10.1002/bies.201700113

Soubry A (2018b) POHaD: why we should study future fathers. Environ Epigenet 4. https://doi.org/10.1093/eep/dvy007

Soubry A, Hoyo C, Jirtle RL, Murphy SK (2014) A paternal environmental legacy: evidence for epigenetic inheritance through the male germ line. Bioessays 36:359-371. https://doi.org/10.1002/bies. 201300113

Suzuki K (2018) The developing world of DOHaD. J Dev Orig Health Dis 9:266-269. https://doi.org/10.1017/S2040174417000691

Tsai D-H, Riediker M, Berchet A, Paccaud F, Waeber G, Vollenweider P, Bochud M (2019) Effects of short- and long-term exposures to particulate matter on inflammatory marker levels in the general population. Environ Sci Pollut Res Int 26:19697-19704. https://doi.org/ 10.1007/s11356-019-05194-y
U.S. Environmental Protection Agency (2020) https://urldefense.proofpoint. $\mathrm{com} / \mathrm{v} 2 / \mathrm{url}$ ? $\mathrm{u}=\mathrm{https}-3 \mathrm{~A} \quad$ www.epa.gov airtrends $\& \mathrm{~d}=\mathrm{DwIDAw} \& \mathrm{c}=$ vh6FgFnduejNhPPD0fl_yRaSfZy 8 CWbWnIf4XJhSqx $8 \& \mathrm{r}=$ SP79iS6nw5Lwa7x8SWJpMcqPRECJMKW59ABrhRjMWaa91THd 7NV1R9 dgX5dzmD\&m=PeV50iiqk9nKx81fXE7GCEJlt6nt4HWiA 1 arsSlzNA\&s=VnPNjzZT0beBnCdIEUudnIdOKb018f7vPcB8kAHroY\&e=air-quality-national-summary. Accessed 15 Dec 2020

Wang L, Fan J, Wang J, Zhao Y, Li Z, Guo R (2020) Spatio-temporal characteristics of the relationship between carbon emissions and economic growth in China's transportation industry. Environ Sci Pollut Res Int 27:32962-32979. https://doi.org/10.1007/s11356020-08841-x

Working Group for the Prevention and Control of Neonatal 2019-nCoV Infection in the Perinatal Period of the Editorial Committee of Chinese Journal of Contemporary Pediatrics (2020) Perinatal and neonatal management plan for prevention and control of 2019 novel coronavirus infection (1st Edition). Zhongguo Dang Dai Er Ke Za Zhi 22:87-90

Wu X, Nethery RC, Sabath MB, Braun D, Dominici F (2020a) Air pollution and COVID-19 mortality in the United States: strengths and limitations of an ecological regression analysis. Sci Adv 6: eabd4049. https://doi.org/10.1126/sciadv.abd4049

Wu X, Wang Y, He S, Wu Z (2020b) PM2.5/PM10 ratio prediction based on a long short-term memory neural network in Wuhan, China. Geosci Model Dev 13:1499-1511. https://doi.org/10.5194/gmd13-1499-2020

Xavier MJ, Roman SD, Aitken RJ, Nixon B (2019) Transgenerational inheritance: how impacts to the epigenetic and genetic information of parents affect offspring health. Hum Reprod Update 25:518-540. https://doi.org/10.1093/humupd/dmz017

Yao Y, Pan J, Liu Z, Meng X, Wang W, Kan H, Wang W (2020) Temporal association between particulate matter pollution and case fatality rate of COVID-19 in Wuhan. Environ Res 189:109941. https://doi.org/10.1016/j.envres.2020.109941

Zhang J, Cai Z, Ma C, Xiong J, Li H (2020) Impacts of outdoor air pollution on human semen quality: a meta-analysis and systematic review. Biomed Res Int 2020:1-9. https://doi.org/10.1155/2020/ 7528901

Zhao Z-H, Schatten H, Sun Q-Y (2017) Environmentally induced paternal epigenetic inheritance and its effects on offspring health. Reprod Dev Med 1:89. https://doi.org/10.4103/2096-2924.216862

Publisher's note Springer Nature remains neutral with regard to jurisdictional claims in published maps and institutional affiliations. 